\section{German Chemists at Munich}

$\mathrm{N}^{\mathrm{G}}$

EARLY three thousand delegates representing thirteen different German societies took part in a national congress of German chemists held at Munich on July 7-11. Prof. P. Duden of Frankfort presided at the general meeting, which was welcomed by Staatsminister Herr Adolph Wagner. Dr. O. Nicodemus of Frankfort delivered an address on the development of the chemistry of acetylene and its national importance as a source of raw materials. From acetylene many derivatives of the vinyl group can be made, which can be developed by polymerization to a great variety of valuable synthetic products. Amongst these may be mentioned the unsaturated hydrocarbons isoprene and butadiene, from which synthetic rubber is made, and a chlorinated derivative, chloroprene, which polymerizes seven hundred times as fast as isoprene and gives rise to an oilproof synthetic rubber. By varying the conditions of polymerization, it is possible to plan the synthesis of products possessing specified physical properties, so that the range of application of these products is increasing rapidly.

Prof. Noack of Berlin then addressed the meeting upon the chemistry and physiology of plant structures. Afterwards the Congress broke up into twenty sections, which met for the discussion of special subjects, full reports of which will be found in the August number of Angewandte Chemie.

Although the main interest of the Congress was in applied chemistry, we find that one section was devoted to the history of chemistry, and a proposal was made to undertake the complete documentation and collection of publications (or copies) relating thereto. In a paper by Dr. Theis of Mannheim, the discovery of catalytic activity was credited to Döbereiner, who described in 1823 the ignition of hydrogen at atmospheric temperatures in the presence of spongy platinum.

Reference can only be made here to a few of the subjects discussed during the sectional meetings. Prof. Hedvall of Göteborg and Prof. Jander of Frankfort discussed reactions between substances in the solid state, Prof. W. Kuhn of Karlsruhe the properties of thread-molecules in solution and Prof. Staudinger of Freiburg the chemistry of macromolecules. Dr. Bredereck of Leipzig described his work on the constitution of the nucleic acids and Dr. Seidel of Munich his synthesis of urobilin. In the sections on applied chemistry will be found numerous papers dealing with fuel-oils, colours, paints, dyes, foodstuffs, building materials, leather, photographic materials, agricultural chemistry and many other subjects.

A whole section has been devoted to the consideration of the rapidly increasing number of Kunststoffe or artificial products. Among those of practical importance we may mention the 'organic' glass of Dr. O. Röhm. This substance, which is free from silicates, is derived from $\alpha$-methylacrylic acid. Esters of the acid are colourless liquids, which polymerize, under somewhat difficult conditions, to vitreous solids, possessing a very high degree of transparency and a low coefficient of expansion. These glasses can be bent and moulded into shape at high temperatures and can be used for making windows for motor-cars and aeroplanes. They can also be used for optical purposes and for the manufacture of apparatus, such as filter-presses.
Another artificial product of first-rate importance is the substance trolitul, formed by polymerization of the hydrocarbon styrene, which is distinguished from most other artificial resins by reason of its excellent insulating properties, resistance to wear and impermeability to water. Thus it can be moulded into insulators and is suitable for employment even where high frequencies are used. The growing use of artificial products in industry has given new interest to the scientific study of complex polymers.

\section{Science News a Century Ago}

\section{Schönbein and Faraday}

In 1836, the long and interesting series of letters began between Schönbein and Faraday which extended over twenty-six years and was afterwards published with notes and comments by G. W. A. Kahlbaum and F. V. Darbishire. The first two letters were from Schönbein, who was then professor of physics and chemistry at Basle. The first was dated May 17 and the second September 12, 1836. Both dealt with experiments on the action of nitric acid on iron and the protective influence of a film of oxide of iron. The most curious thing Schönbein said he had observed was that iron wire could be made in. different to nitrie acid. Previous to this second letter, Faraday had communicated an account of Schönbein's investigations to the Philosophical Magazine, and in his letter of September 12 Schönbein wrote: "I feel much obliged to you for the kind manner in which you mentioned my late researches on iron in the philosophical Magazine. It is this kindness which encourages me to address to you a second letter on the same subject".

\section{Worcestershire Natural History Society}

UNDER the above heading, the Analyst, 5, 160 (1836), records: "The ceremony of opening the museum of this Society took place on the 13th of September; on which occasion upwards of eight hundred persons attended, including a large proportion of the inhabitants of the county and city distinguished for their literary and scientific attainments. The Bishop of Worcester entered the room about twelve o'clock accompanied by the members of the council and at the request of the Hon. and Rev. J. S. Cocks took the chair". His lordship in a short speech congratulated the members of the Society upon the completion of the building and then called upon Dr. Hastings to deliver the inaugural address, "which was listened to with marked attention, and frequently elicited very considerable applause". About a hundred members and friends afterwards dined together, some admirable speeches were made and it was gratifying, said the Analyst, "to observe the interest which the prosperity of the Society appeared to excite".

\section{De la Rue on Voltaic Electricity}

THE first scientific paper of Warren De la Rue (1815-89) was a communication to the editor of the Philosophical Magazine dated September 15, 1836, and entitled "On Voltaic Electricity, and on the Effects of a Battery charged with Sulphate of Copper". "The greatest effect," the author said, "being always produced in those voltaic arrangements where the chemical agent exerted an action on 
only one of the metals constituting the battery, it occurred to me to use a saturated and perfectly neutral solution of the electro-negative metal, provided the other was capable of effecting its decomposition. I therefore tried the effect of a saturated solution of sulphate of copper in an elementary voltaic battery of the ordinary construction". After describing various experiments with his battery, he said, "It is worthy of notice, that after the batteries have been in action some time, a large proportion of the sulphate of copper is expended, and replaced by sulphate of zinc, yet the action continues the same. This naturally suggests using a saturated solution of any neutral salt, common salt, for example, and adding merely as much as the solution of copper as will serve for the time required. . . . I intend trying this, as I am still pursuing my inquiries on this subject, the object of which is to simplify as much as possible the voltaic battery. ..."

\section{Death of Antoine-Laurent de Jussieu}

ON September 17, 1836, the celebrated French botanist, Antoine-Laurent de Jussieu, died in Paris at the age of eighty-eight years. The nephew of the three brothers Antoine, Bernard and Joseph de Jussieu, who all contributed to botanical science, Antoine-Laurent was born at Lyons on April 17, 1748. On leaving school at the age of seventeen years, he joined nis uncle Bernard de Jussieu (16991777) who was then a demonstrator at the Jardin du Roi in Paris, and after taking a degree in medicine became an assistant in the same institution. The collection of plants at that time was arranged according to the system of Tournefort. It becoming necessary to rearrange them, Jussieu adopted a new system suggested by what his uncle had done at Trianon, and from this grew the natural system described by Jussieu in his book "Genera Plantarum" published in 1789 , the year in which the Revolution broke out.

As with so many other men of seience, Jussieu for a time found his labours interrupted by the political upheaval, and in 1790 he became a member of the municipality of Paris, of which Bailly was Mayor, and was charged with the direction of the hospitals and charities of the city. In 1793, when the Jacobins came into power, the Jardin du Roi was reorganized as the Jardin des Plantes and Muséum d'Histoire naturelle, and Jussieu was made professor of rural botany. His colleagues included Lamarck, Daubenton, Saint-Hilaire, Fourcroy and Brongniart. $\mathrm{He}$ afterwards became director and treasurer of the museum and a professor in the faculty of medicine. In 1822 he severed his connexion with the school of medicine and four years later resigned his chair at the Jardin des Plantes, and was succeeded by his son, Adrien de Jussieu (1797-1853).

The natural system of classification of plants introduced by Jussieu was not appreciated at first as it ought to have been, and it was not until the writings of Robert Brown (1773-1858) that it made any headway in Great Britain. Besides his "Genera Plantarum" Jussieu wrote many memoirs, in 1796 published his "Tableau synoptique de la méthode botanique" and in 1800 his "Tableau de l'école de botanique du Jardin des Plantes". A statue of him now stands in the vestibule of the botanical gallery of the gardens. His son, who also was director of the museum, died leaving no male heirs, and the family, which for a century had been an ornament of science in Paris, became extinct.

\section{Societies and Academies}

Paris

Academy of Sciences, July 20 (C.R., 203, 217-288).

LuCien Cayeux: The coproliths of the North African phosphates. These coproliths consist of ealcium phosphate, almost entirely free from organic or mineral inclusions.

LouIS BLARINGHEM : The temperature of the spadices of Arum italicum. The temperatures art higher than the surrounding air: possible reason for this are discussed.

Louis Bouvien : Observations from the crayfisl on the constitution of the side of the body-wall is the Crustacea.

Alexandre Guthliermond and MLle. N. Chou CROUN : An attempt at electrophoresis in the interio of plant cells.

Meinder HaImovicr : Integral geometry on curver surfaces.

Norbert Wiener and Szoliem MandelbroJt Lacunar Fourier series. Inverse theorems.

Jean Mandel: The crumpling of a tube in resistant elastic medium.

Albert Portevin and Léon Guillet, jun. : Th elastic modulus of certain definite intermetallic com pounds. Of the six compounds studied, $\mathrm{CuZn}, \mathrm{Ag}_{3} \mathrm{~S}$ and $\mathrm{MgZn}_{2}$ obey the rule of mixtures, the other: $\mathrm{Cu}_{31} \mathrm{Sn}_{8}, \mathrm{Cu}_{8} \mathrm{Al}_{4}$ and $\mathrm{CuZn}_{6}$ give elastic moduli 20-4 per cent higher than those calculated from the mix ture mule.

Choong Shin-Praw: New systems of bands c selenious anhydride, $\mathrm{SeO}_{2}$, of selenium, $\mathrm{Se}_{2}$, and ( tellurium, $\mathrm{Te}_{2}$, in the ultra-violet.

Nx Tsi-Ze and CH'EN SHANG-YI: The displace ments of the higher members of the principal serit of rubidium by the rare gases. Study of the di placement of the lines of the spectrum of rubidiu by helium (up to $12 \cdot 75$ atmospheres), neon (up $t$ 13.59 atmospheres) and argon (up to $7 \cdot 12$ atm spheres).

ANDRE LALLFmand : The application of electron optics to photography.

Jean Reboul : A possible correlation between th intensity of the cosmic radiation and the velocity certain chemical reactions.

Prerre Auger and Mme. Grivet-Meyer : Analys of cosmic ray bundles by utilization of their dive gence.

René Dubrisay and JacQues Lefol: Study the saline hydrates. The salt and a direct readi balance are placed under a bell-jar over a hygroscop substance under reduced pressure, and the loss weight studied as a function of the time. Wi crystallized copper sulphate over phosphoric a hydride, the curve of loss shows a sharp angle $5 \mathrm{H}_{2} \mathrm{O}$, and after ten days the weight is constant $1 \mathrm{H}_{2} \mathrm{O}$. Over dilute sulphuric acid (pressure of wat vapour $0.85 \mathrm{~mm}$.), $\mathrm{CuSO}_{4}, 3 \mathrm{H}_{2} \mathrm{O}$ is the final produc

RENÉ DALMON: Heats of mixture of sulphu and nitric acids free from water.

Mlle. Vatérte Deutsch: The adsorption proteins. The serum albumen of the horse.

E. RINCK : Diagram of solidification and electric conductivity of the potassium-cæsium alloys.

Henri Moureu, Michel Magat and Georg WETrofF : The two forms of phosphorus pent chloride. From a study of the melting and solidific tion curves of phosphorus pentachloride there wor 